\title{
An Analytic Study of Ironic Statements in Ahlam Mistaghanmi's Their Hearts with Us While Their Bombs Launching towards Us
}

\author{
Hayder Tuama Jasim Al-Saedi \\ English Department, College of Basic Education, Misan University, Maysan, Iraq
}

\begin{abstract}
The study investigates the hidden (figurative) meaning behind the literal meaning of the ironic statements in the Arabic texts. The linguistic and psychological literature shows the controversy around the theory of Irony. The data had been collected from "Their Hearts with us while Their Bombs Launching Towards us," which is written by the Arabic writer Ahlam Mistaghanmi. The book is full of the ironic statements, which address the Iraqi situation. The data had been translated to Arabic by an English-Arabic translator. The data being analyzed is based on Irony. The conclusions find out that the selected data show that there is an intended/ hidden message behind each statement, which is conveyed to her readers ironically.
\end{abstract}

Index Terms - irony, ironic statements, Ahlam Mistaghanmi, hidden (figurative) meaning

\section{INTRODUCTION}

Irony is one of the linguistic features used in human communication to make sarcastic and humorous situations. It is defined as "a term which has a range of meanings that involve some sort of discrepancy or incongruity" (Arp \& Johnson, 2006). There are three types of irony; namely, verbal, dramatic, and situational. The purpose of the verbal irony is to make sarcasm because the speaker says the opposite of the literal meaning to intend the figurative meaning behind the literal one. In the dramatic irony, the reader knows something about the character where the character does not know it. It could be truth about the character or the character's expectations. Finally, irony of situation, which is the focus of this study, can be created when the authors 'suggest complex meanings without stating them,' and it is essential in fiction (Arp \& Johnson, 2006).

Ironic expressions have had different interpretations based on different theoretical points of views. The Traditional Views of Irony or the Standard Theory of Irony assumes that it is opposite to the literal meaning, which is contextually inappropriate (Searle, 1979). Moreover, it obviously violates the maxim of quality (Grice, 1975; 1978). It requires deriving an interpretation by the receiver (listener/reader). Consequently, it violates the norms of cooperative communication because understanding irony requires being tacitly recognizable (Gibbs and O'Brien, 1991). Sperber and Wilson (1981) state that Grice's irony does not show a figurative meaning behind the literal meaning of an expression. They give an example about weather where it was described lovely based on the weather bureau. However, it was the opposite. For this reason, ironically, the speaker said it was lovely to mean the opposite meaning behind the literal meaning of "lovely Weather." In other words, Sperber and Wilson reveal that this example does not hold figurative meaning behind the literal meaning of irony.

Another viewpoint to analyze the ironic meaning was by Sperber and Wilson. Their theory is called the Echoic Mention theory (Sperber \& Wilson, 1981). It reflects the speaker's attitudes to understand the ironic meaning where it reminds the listener with the propositional cues to get the ironic meaning. Jorgenson et al (1984) tested this theory and they found out that it needs an echoic mention to understand the ironic, intended meaning. In addition, when there is a contextual mention in the ironic utterance, this makes it more ironic. Consequently, context plays a role to determine ironies.

The Echoic Mention Theory was developed to include the function of reminding the listener/ reader to understand the ironic utterances. Besides, not all the mentions are echoic (Kreuz \& Gluckberg, 1989). It is ironic when people allude to or echo the societal norms and generalized expectations. For this reason, the theory was modified to be the Echoic Reminder Theory. Kreuz and Glucksberg (1989) claim that positive and negative statements of irony can determine the ironic meaning of the utterance. Positive utterances allude to the societal norms and expectations. They do not need to explicit antecedents to convey the ironic meaning; they can be conveyed implicitly. On the other hand, negative ironic statements need to explicit antecedents to understand the ironic meaning. Consequently, Gibbs and O'Brien (1991) state that the echoic reminder mention "alludes to prior occurrences or states of affairs." Respectively, the following are some examples of positive and negative ironies:

-What a clever boy! It means what a stupid or idiot boy.

-What a terrible friend! It means what a great or good friend. 
There is controversy about the theory of irony, which claims that it is not echoic mention or reminding, but it involves "Pretense." When the listeners recognize the pretense from the context, they should know that the speakers intend to be ironic. The purpose of this view is to pay attention to the derogation of both the speaker and listener's attitudes. It is called The Pretense theory of Irony which was proposed by (Clark \& Gerrig, 1984). They theory was based on the views of Grice $(1975 ; 1978)$ and Fowler $(1965)$. In short, they claim that the Pretense theory is outstanding in comparison with the Mention theory which was proposed by Sperber and Wilson.

Clark and Gerrig (1984) cite and analyze Jonathan Swift's essay A Modest Proposal (1971) about poor children. They (ibid) consider it a piece of irony because they think that the speaker is pretending that he or she let the addressees or audience to discover his or her pretense and have their attitudes toward the speaker. In other words, they consider that Swift pretended to be a member of English ruling class and expected his readers to know his pretense and attitude about the rich and poor children.

In the same vein, Giora (1995) claims that irony is an indirect negation. It requires activating the negated and implicated messages of the ironic utterances. She reveals that irony is a strategy of politeness. It enables the speaker to use affirmative statements to show the negated or opposite meaning. The purpose behind that is to reduce the aggressiveness of negation which can be expressed by direct statements. For this reason, she suggests use indirect, affirmative statements to show ironies.

Beside the linguistic literature, psychological findings played a role to test the theories of irony. The traditional views of irony assume that the interpretation of the ironic meaning can be conveyed to the listener based on the context, but it does not show any recognition of the ironic meaning (Gibbs, 1984; 1986a; 1989). The violation of communicative norms takes less time to comprehend and to interpret the ironies although the traditional views reveal the opposite (Gibbs, 1986a). In the same vein, the findings prove that indirectness of irony takes longer time to be understood (Gibbs, 1986b).

Sarcastic ironies can be more ironic when the context has a previous mention. Furthermore, they can be comprehended when they include explicit echoes. In addition, positive ironic statements, the echoic reminder theory, are more ironic than negative ones (Gibbs, 1986a). However, the Pretense Theory of irony does not have any empirical studies to prove its psychological findings (Gibbs \& O'Brien, 1991). They made two scenarios about two students (John and Bill) who took statistics class. The scenarios have different situations but they end with the same sentence which is "I would never be involved in any cheating." The findings proved that ironies can be intentional and unintentional. Less time can be paid to understand the unintentional statements of irony than the intentional ones, which take longer to be processed.

Because each text conveys a message, which is sometimes behind the literal meaning, not all readers may be aware of this message. For this reason, this study aims to analyze the selected texts in Ahlam Mistaghanmi's book (See Data Collection) based on the Irony theory to make the reader aware of intended meaning (figurative meaning) behind the literal meaning of the ironic statements in her book.

\section{DATA COLlection}

The data is Arabic texts from Mistaghanmi's book "Their Hearts with us while Their Bombs Launching Towards us." The researcher asked an expert in English-Arabic translation, Mr. Falah Alsarri, the translator in Misan University/ College of basic Education, to translate the selected texts, which are the target data in this study. The reason behind that is to have the exact translation of the selected texts, which make the reader have the same ideas after the translation. Then, the researcher applied ironic approach to analyze these texts

Mistaghanmi is one of the Arabic novelists and writers that she is used to pleasing her readers with her great literary works. Her book "Their Hearts with us while Their Bombs Launching Towards us" includes the articles that published by the novelist; the articles discussed the Iraqi situation. In other words, the book tells us that the writer has a high experience and has read a lot about what happened in Iraq before 2003 and after the coalition invasion to the Iraqi soil. She gives good background about the people who are responsible for the destruction and damage that is happening in Iraq. She used her literary talent to view the details of the Iraqi case using the situational irony to convey her message pragmatically about the tragedy of Iraqis, which happens every day because of the policy that led it to this kind of situation. She criticizes the mentioned characters in her book ironically. Thus, this paper focused on the ironic statements in her book and is analyzed pragmatically.

\section{DATA Analysis AND Results}

The following are the selected texts analyzed by the researcher to make the readers recognize the hidden message behind each ironic statement from the texts, which have been collected:

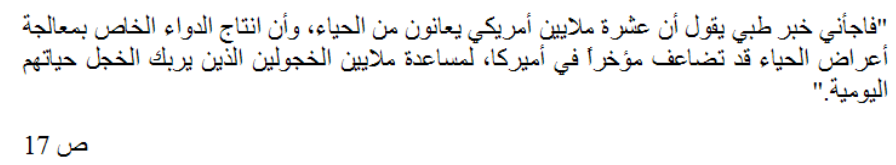


An American medical report made me astounded. The report is that around 10 million of the US population undergo shyness. The report added that shyness medication products expanded lately in the US to render some help for shyness disease victims.

Page (17)

Shyness is not a disease. It does not have symptoms. It can be expressed facially or gesturally. Moreover, there is no physical medication to treat shy people. The writer tries to tell us ironically about the policy that is followed by the American politicians and she does not know the American people except their politicians who lead wars against the other countries in case of fighting terrorism. She used "shyness" to describe that there is no shyness in America when they want to declare something such as the war.

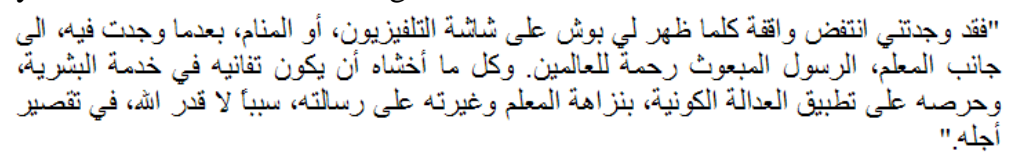

22 ص

I pay more attention when I see Bush on TV or in sleeping. Besides what I know about all his qualifications as a teacher, he is an emissary messenger as mercy to the world. All I am afraid of is about his self-denial for humankind service, his sincerity to apply the sky's justice. His efforts to spread his message can be a reason to shorten his age.

Page (22)

In this example, Mistaghanmi describes George W. Bush as the messenger who was chosen by God to bring mercy for the whole universe. As we know, Bush was the president of the United States and he is not the God messenger. In addition, he did not bring justice to the humankind because he lied to media that Iraq had nuclear weapons. It was a good reason to declare the war against Iraq. Even Americans, not just the Iraqis and the whole world, were not satisfied with the war against Iraq. America lost a lot of its soldiers and money to support their war.

Ironically, based on Mistaghanmi's idea, the declaration of war made the President Bush to be the "selector" to save the world from terrorism, which is the opposite because the Iraqi infrastructure and humanity have been destroyed by this war. That is why she used ironic expressions to describe the actions of the US president Bush to invade Iraq as an excuse of fighting terrorism.

Besides the ironic statements about the American power, the following example describes irony based on an Iraqi politician:

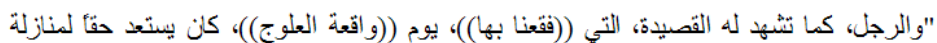

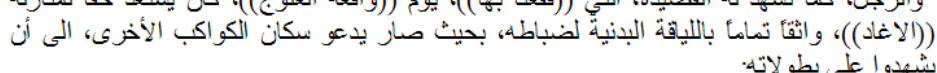

$$
\begin{aligned}
& \text { اطلق لها النيف لا خوف ولا وجل أطلق لها السيف وليشهـ لهازحل" }
\end{aligned}
$$

83 ص 83

The poem that uttered by the former Iraqi president Saddam Hussein at the day of "Al'alooj Battle," is an example that the Iraqi army had prepared to challenge and fight the "Villains." He was confident that his soldiers' physical fitness. He exceeded his limits of confidence until he started to invite his torments as in the following verse:

Release the swrod for it

No scare no fear

Release the sword for it

Let Saturn certifies for it.

Page (83)

"Al'alooj Battle" implies the speech of the Iraqi minister of media "Mohammed Saeed Alsahaf" when he described the American forces as "Al'alooj." In Arabic, literally, the word means the strong zebra or strong man. However, he mentioned that in his speech to tell the Iraqis and world that they are strong and firm in the battle. The American forces cannot defeat them. But, in reality, they invaded most parts of Baghdad when he mentioned it. The word "Al'alooj" is used ironically in the Iraqi and Arab societies. Mistaghanmi used the word indirectly to tell her readers the ironic way of invading Iraq although Saddam Hussein motivated his supporters with his verse trying to assure them that they get the victory in this war.

The lies that are mentioned reveal that Iraq had nuclear weapons. The next example states the ironic way to describe the lies of having this kind of dangerous weapons.

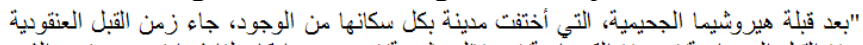

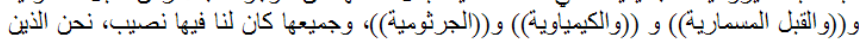

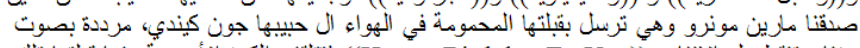

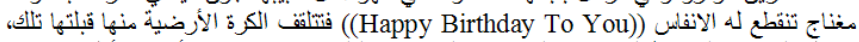

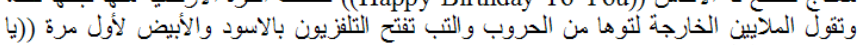

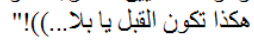

ص 120

Thus, after the hell of "Hiroshima kiss," which caused to vanish the whole city with all of its residents from the being, it is the time of "cluster, flechette, chemical, bacterial kisses. We got our portion of all of these kisses. We all trusted 
Marlene Monroe when she sent her warm kisses to her beloved "John Kennedy" with disputed "Happy Birthday To You." Earth catches her kisses and she says that millions of people who just got out the wars watching it on black and white Tv for the first time "kisses be like Marlene's or not to be."

Page (120)

Mistaghanmi mentions some ironic utterances in a metaphorical way. For example, she describes the bombs that hit different parts of the Globe such as Hiroshima as "kisses" by the American forces in the World War II. Moreover, they developed new weapons to examine them to attack Iraq with their new bombs in 2003. Ironically, she described attacking Iraq with these chemical weapons the same way that Marlene Monroe sent her kisses to the American President John Kennedy to tell him "Happy Birthday to you." In the same vein, metaphorically, Mistaghanmi tries to tell her readers that the Iraqi people faced the bombs that the same way Marlene Monroe's audience faced her warm kisses at that time. The American air forces stroke Iraq with their kisses "bombs" from their F16 planes. Ironically, Mistaghanmi describes it using the oppositeness to give the intended meaning of facing the bombs with damage, destruction and a lot of people were killed or wounded in this war.

Besides, Mistaghanmi used the closeness of pronouncing the Arabic words "bomb" and "kiss" to express her irony to criticize the American policy when declaring the war against the Iraqi former regime to save the Iraqis. The pronunciation of word "Kiss" is [qubla?] and "bomb" is [qunbla?]. Therefore, this closeness expressed the oppositeness of the meanings of the two words. Kisses give love and good, but bombs can give evil and damage. To rescure Iraqis from the dictatorship of Saddam's regime, they need to use different kinds of bombs, which are forbidden based on the international laws declared by the United Nations.

Two other examples of irony describes the worst person in the history of Iraq; he is Udi (the oldest son of the former president Saddam Hussein).

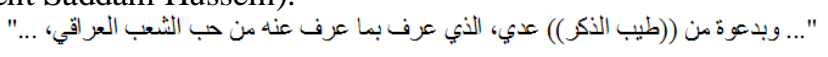

ص86

... got invited by Udi who has a "good reputation" and the Iraqi people love him, ...

Page (86)

$$
\text { أذكر ان طيب الذكر، عدي، كان في اخر عيد ميلاد 》 القائد 《)... }
$$

ص69

I remember that a person who has "good reputation" in the last anniversary Saddam's birthday

Page 69

Indirectly, Mistaghnmi wants us to know that Udi, the oldest son of the Iraqi former president, Saddam Hussein, has a bad reputation. She mentions "a good reputation" to make us infer the opposite meaning of his popularity by showing it in an ironic way. Moreover, she mentions the love of Iraqis to Udi to tell us ironically that he was not loved by Iraqis because they used to hate him. He used to use violence against people around him. He used to rape any girl he wanted to and kill them after he had got whatever he wanted. In short, the opposite meaning of the Ironic statements plays a role in these two examples to show irony about Udi whose persona was not accepted by Iraqi. For this reason, Mistaghanmi used positive meaning to show the negative side of the president's son Udi.

Another example of irony, which holds sense of humor about the myth of having nuclear weapons, is in page 44 . In this example Mistaghanmi reveals this kind of myth ironically.

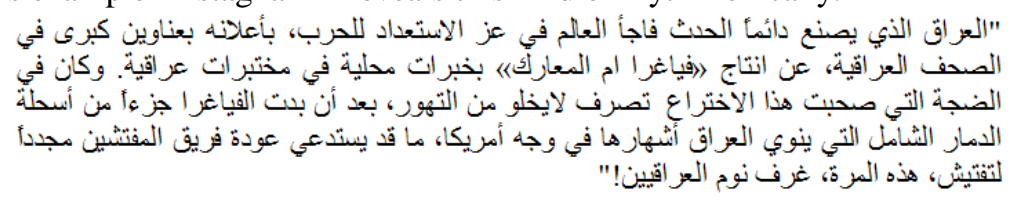

ص44

Iraq, always creates the event, surprised the world while It was getting ready for the war, announcing, throughout Iraqi Newspaper Headlines "Viagra Um Alma'arik (Viagra of Mother of Battles)" produced it by local expertise in Iraqi labs. There was impetuousness conduct, synchronized with that aberrations, Viagra seemed to become part of the mass destruction weapons which Iraq intends to use it against America, this may call inspectors team to back again for searching to find these weapons, but this time, they will search inside the Iraqi rooms.

Page 44

Mistaghanmi mentions "Viagra Um Alma'arik" which literally means Viagra of Mother of Battles. The name "Um Alama'arik" was called by the former president of Iraq Saddam Hussein in 1990 on the Gulf War where Allies which were led by the United States declared the war against Iraq after the invasion of Kuwait. However, there is no connection between "Viagra," which is as you know it is kind of pills that use to help to have sexual intercourse, and the war which called by Saddam Hussein as "Um Alama'arik." Mastaghanmi tries to tell her readers that the war was declared by the Americans because Iraq had nuclear weapons. The word "nuclear" pronounced as [næwæwi] and the word "sperm" pronounced as [mænæwi]. These two words are different but they have the same tone. Ironically, she tries to tell the world that Iraqis were busy in their normal life not developing nuclear weapons or mass destruction weapons. Moreover, she tells the world that the weapons that were developed in the labs were bedrooms in which the 
Iraqis were having intercourse using the Viagra not nuclear weapons. Consequently, the world has to know the myth that declared by the Former president of the United States George Bush that Iraq has mass destruction weapons and it was a threat to the United States and world. The role of Americans, here, is to eliminate Saddam's regime.

Mastaghanmi used ironic statement by combing words such as nuclear and sperms to tell the world the liars that were led by the American president George Bush against Iraq to destroy the Iraq and get its natural recourses by a mythical excuse which is fighting terrorism and destroying the mass destruction weapons. Therefore, irony plays a role to this example to show the facts of war against Iraq.

Finally, the following example shows the most ironic way to describe the people who are in charge of the White House:

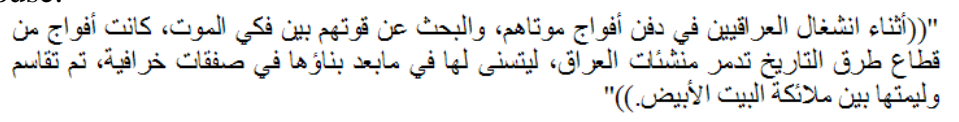

ص178

While Iraqis were busy to bury their dead bodies and looking for their bread between the jaws' doom, there were bands of historical bandits devastating to Iraq institutions. That action will enable them to reconstruct these utilities in fabulous deals. Deals' benefits had been distributed already among the angels of the White House.

Page (178)

By the end of this example, Mistaghanmi says "angels of the White House" to imply the "devils of the White House" especially the former president George W. Bush. The reason behind that is that these angels (devils) destroyed the Iraqi infrastructure to tell the world that Saddam's regime had nuclear weapons and it supports terrorism in the world. On the other hand, the white House had persuaded the American people through media with their lies to declare the war against Iraq which led to kill a lot of the American soldiers. Consequently, as victims, both the Iraqi and American people paid the price because of this war.

When she said "angels," she wants us to get the opposite meaning of it ironically because the war made Iraq a field for the robberies and to get the trophies distributed among the people who are responsible for the destruction that happened in Iraq. After the invasion of Baghdad, a lot of the thieves entered, for example, the National Museum to rob the Iraqi heritage. They smuggled the relics abroad. In addition, a lot of money were robbed from the Iraqi banks. Moreover, the Iraqi oil was under the control of the American forces, which made them send it abroad and make the "angels of the White House" fill their bank accounts with millions of the US dollars from the Iraqi oil. Mistaghanmi, ironically, tries to tell her readers about the conspiracy that led by the White House administration to rob the Iraqi wealth and heritage. In short, the situational irony gives Mistaghanmi the talent to make her readers reveal the intended meaning behind the text in this paragraph.

\section{CONCLUSIONS}

The findings reveal that Mistaghanmi used the oppositeness to present the ironic statements to her readers about the Iraqi situation before and after the war in 2003, which brought destruction and damage to Iraq. Therefore, she have made it easy for her readers to get the intended meaning behind the literal meaning of the statements in her selected book in this study. The intended meaning of the collected data had been shown by taking the opposite expressions of each ironic statement in this study.

\section{ACKNOWLEDGEMENTS}

The researcher would like to thank Mr. Fallah Hussein Alsarri (Misan University) for his accuracy to translate the selected texts, which are needed in this study to analyze it based on the irony theory. Thus, the researcher would like to thank Asst. Lecturer Mr. Khalid Wahaab Jabber (Misan University) and Asst. Prof. Dr. Fatima Rahim (Misan University) for giving feedback to improve this paper. Finally, I would like to thank Prof. Dr. Alaa Hussein and his colleagues from Basrah University for giving the most useful feedback for this study.

\section{REFERENCES}

[1] Arp, T. R., \& Johnson, G. (2006). Perrine's Literature: Structure, Sound \& Sense. Boston: Thomson Wadsworth.

[2] Clark, H. \& Gerrig, R. (1984). On the pretense theory of irony. Journal of Experimental Psychology: General 113: 121-126.

[3] Fowler, H. W. (1965). A dictionary of modern English usage (2nd ed.). Oxford: Oxford University Press.

[4] Gibbs, R (1986b). Comprehension and memory for nonliteral utterances: The problem of sarcastic indirect requests. Acta Psychologica 62: 41-57.

[5] Gibbs, R. (1984). Literal meaning and psychological theory. Cognitive Science 9: 275-304.

[6] Gibbs, R. (1986a). On the psycholinguistics of sarcasm. Journal of Experimental Psychology: General 115: 3-1 5.

[7] Gibbs, R. (1989). Understanding and literal meaning. Cognitive Science 13: 243-251.

[8] Gibbs, R. W., \& O'Brien, J. (1991). Psychological aspects of irony understanding. Journal of pragmatics, 16(6), 523-530.

[9] Giora, R. (1995). On irony and negation. Discourse processes, 19(2), 239-264.

[10] Grice, H. P. (1975). Logic and conversation. In: Peter Cole and Jerry Morgan, eds., Syntax and semantics, Vol. 3: Speech acts (pp. 41-58). New York: Academic Press. 
[11] Grice, H. P. (1978). Further notes on logic and conversation. In: Peter Cole, ed., Syntax and semantics, Vol. 9: Pragmatics, $113-$ 127. New York: Academic Press.

[12] Jorgensen, J., Miller, G., and Sperber, D. (1984). Test of the mention theory of irony. Journal of Experimental Psychology: General 113: 112-120.

[13] Kreuz, R. \& Glucksberg, S., (1989). How to be sarcastic: The echoic reminder theory of verbal irony. Journal of Experimental Psychology: General 118: 374-386.

[14] Searle, J., (1979). Metaphor. In: Andrew Ortony, ed., Metaphor and thought, 92-123. New York: Cambridge University Press.

[15] Sperber, D. \& Wilson, D. (1981). Irony and the use-mention distinction. In: Peter Cole, ed., Radical pragmatics, 295-318. New York: Academic Press.

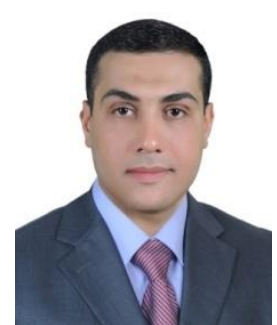

Hayder Tuama Jasim Al-Saedi received his Master's Degree (2013) in Applied Linguistics from Southern Illinois University at Carbondale (SIUC). He got a diploma (2011) in English as a Second Language from the Center of English as a Second Language (CESL) at (SIUC). He got his Bachelor's Degree (2005) in English at Misan University. He was an assistant researcher (2006-2010) in Department of English at Misan University. He worked as assistant instructor (2014-2017) in Department of English at Misan University. Currently, he works as an instructor (2017-present) in Department of English at Misan University. He is a member of different committees in Misan University. He has published articles in his major and participated in conferences and workshops. His research interests include Applied Linguistics and English as a Foreign Language. His orcid ID is: https://orcid.org/0000-0003-0214-3542. My research gate profile is: https://www.researchgate.net/profile/Hayder_Al-Saedi2. 